\title{
Changes in biomass and elemental composition during early ontogeny of the Antarctic isopod crustacean Ceratoserolis trilobitoides
}

\author{
Olaf Heilmayer $\cdot$ Sven Thatje $\cdot$ Christine McClelland \\ Kathleen Conlan · Thomas Brey
}

Received: 8 March 2008/Revised: 5 May 2008/Accepted: 14 May 2008/Published online: 14 June 2008

(C) Springer-Verlag 2008

\begin{abstract}
Changes in biomass and elemental composition (dry mass, DM; carbon, C; hydrogen, $\mathrm{H}$; nitrogen, $\mathrm{N}$ ) were studied throughout the early ontogeny in the serolid isopod Ceratoserolis trilobitoides from a population off the South Shetland Islands $\left(62^{\circ} 24.35^{\prime} \mathrm{S}, 61^{\circ} 23.77^{\prime} \mathrm{W}\right)$. Specimens of C. trilobitoides were sampled using an Agassiz trawl during the expedition ANT XXIII-8 of RV Polarstern in January 2007. Classification of embryos into six developmental stages followed previous studies. No clear sizedependant fecundity relationship was found in ovigerous C. trilobitoides. Egg volume increased by about 160 and $400 \%$ from stage I to IV and stage IV to VI, respectively. $\mathrm{DM}, \mathrm{C}, \mathrm{N}$, and $\mathrm{H}$ continuously decreased throughout the early ontogeny from stage I to VI, but DM showed significant increase on reaching the late- $\mathrm{V}$ stage and premanca stages. The $\mathrm{C}: \mathrm{N}$ ratio remained relatively stable throughout stages I to $\mathrm{V}$, followed by a significant drop from about 6.17 to 5.5 in subsequent stages, indicating depletion of lipid resources of maternal origin. The results coincide with previous studies and indicate a shift from a lipid-based metabolism throughout early embryo stages to a protein-
\end{abstract}

O. Heilmayer $(\bowtie) \cdot S$. Thatje

National Oceanography Centre, Southampton,

School of Ocean and Earth Science,

University of Southampton, European Way,

SO14 3ZH Southampton, UK

e-mail: oheilmayer@noc.soton.ac.uk

O. Heilmayer · T. Brey

Alfred Wegener Institute for Polar and Marine Research,

Marine Animal Ecology, Am Handelshafen 12,

27570 Bremerhaven, Germany

C. McClelland · K. Conlan

Canadian Museum of Nature, P.O. Box 3443,

Ottawa, ON K1P 6P4, Canada based metabolism in the late- $\mathrm{V}$ and premanca stage, which requires external energy supply. Given the steep increase in $\mathrm{DM}$ in the final phase of embryo development (late- $\mathrm{V}$ stage to premanca) and the need for external food supply to exert growth, the possibility of external food supply or cannibalism in early offspring of $C$. trilobitoides is discussed.

Keywords Invertebrate reproduction - Cold adaptation . Serolidae $\cdot$ Peracarida

\section{Introduction}

Peracarid crustaceans constitute one of the most conspicuous faunistic elements of the Antarctic benthos both in terms of abundance and diversity (e.g. De Broyer and Jazdzewski 1993; Rehm et al. 2006). Their diversity is discussed to be due to late-Cenozoic radiation and diversification in the course of Antarctic cooling (Brandt 1991; Lörz and Held 2004). Among other factors, the reduction of predatory pressure, as a consequence of the extinction of most seafloor predators during Antarctic cooling, may have favoured peracarid radiation and speciation over long evolutionary timescale (Aronson et al. 2007).

Little is known of peracarid physiology in general and mechanisms of cold adaptation. A striking question remains why all peracarid crustaceans, except some parasitic forms (e.g. Raupach and Thatje 2006) do follow a direct reproductive mode and exert strong brooding behaviour. This is of special interest with respect to the success of this group in polar seas given the reduction of pelagic larvae and/or drifting stages when compared with overall benthic diversity (Thorson 1936; Thatje et al. 2005; Gutt 2006). The predominance of brooding species in the Antarctic benthos and especially in the peracarid 
crustaceans was often proposed a key factor for the success of this group in the Southern Ocean (e.g. Picken 1980; White 1984; Pearse et al. 1991). At local scale, however, Stanwell-Smith et al. (1999) showed that the diversity of marine invertebrate larvae at Signy Island (Antarctica) was similar to that reported by Thorson (1950) from a single non-polar region (Denmark). The abundance of larvae was lower, giving the impression of lower diversity.

The reproduction of many broadcasting taxa is known to follow latitudinal patterns in reproduction, which i.e. include a reduction in fecundity, increase in egg size and energy per offspring with increasing latitude (Clarke et al. 1985; Shilling and Bosch 1994; Fischer and Thatje 2008). Such reproductive patterns seem evident at least in decapod crustaceans, prosobranch molluscs, and echinoderms (Thorson 1936, 1950; Clarke 1979; Clarke et al. 1985; Pearse et al. 1991; Thatje et al. 2005). However, the mechanisms driving latitudinal patterns in reproduction are far from being fully understood although often related to adaptations to decreasing temperature and more pronounced seasonality towards higher latitudes (Clarke 2003; Pearse and Lockhart 2004; Thatje et al. 2005; Fischer and Thatje 2008).

Ceratoserolis trilobitoides (Eights 1833) is one of the larger and frequent Antarctic crustaceans and its taxonomy (Held 2000; Leese and Held 2008) and reproductive biology (Wägele 1987; Luxmoore 1982; Clarke and Gore 1992) is among the better-understood ones within the Antarctic Peracarida. Energetic studies in brooding peracarids are scare, but there has been evidence that egg size and biomass in Ceratoserolis trilobitoides increase with lower temperatures and that such patterns express within relatively moderate temperature changes at low temperatures within the Southern Ocean (Wägele 1987; Clarke and Gore 1992). Understanding energetic trade-offs in peracarid reproduction may be one clue to elucidating the success of this group globally.

In this study we present ontogenetic changes in biomass and elemental composition of early ontogenetic stages of Ceratoserolis trilobitoides from waters off the Antarctic Peninsula. The results are discussed within the context of reproduction in the cold and by taking into account previously published aspects of the reproductive biology of this species.

\section{Material and methods}

\section{Sampling}

Serolids were sampled in January 2006 by Agassiz trawl (mouth opening $1 \times 3 \mathrm{~m}, 20 \times 20 \mathrm{~mm}$ mesh size in the front part, $10 \times 10 \mathrm{~mm}$ in the cod end) during the $\mathrm{RV}$ Polarstern expedition ANT XXIII-8 (Gutt 2008). For this study, only individuals from one station at the Southern Shetland Islands $\left(62^{\circ} 24.35^{\prime} \mathrm{S}, 61^{\circ} 23.77^{\prime} \mathrm{W}\right)$ were used. Immediately after the catch, specimens were transferred to a temperature controlled water tank and maintained at $0^{\circ} \mathrm{C}$ for further analyses. After determining the embryonic stage, individuals were frozen at $-30^{\circ} \mathrm{C}$. Upon return to the Alfred Wegener Institute (Bremerhaven, Germany) animals were subsequently dissected while a small piece of tissue of each individual was used to confirm the exact taxonomic status using recently developed microsatellites (for details see: Held 2003; Leese and Held 2008) (analysis kindly performed by C. Held, AWI, Bremerhaven). All specimens belong to the type Ceratoserolis trilobitoides sensu stricto (Eights 1833, group 2 in Held 2003). The total length (TL) of all animals was measured with digital calipers to the nearest $0.1 \mathrm{~mm}$. Animal dry mass (DM) was determined after $48 \mathrm{~h}$ oven-drying at $60^{\circ} \mathrm{C}$. A total of ten gravid Ceratoserolis trilobitoides bearing eggs of different developmental stage were used in this study.

Egg size, number, volume, and stage

All eggs from ten ovigerous females were removed. A random subsample of 16 eggs/female was measured to the nearest $0.01 \mathrm{~mm}$ using a dissecting microscope (Wild M3) equipped with an ocular micrometer. Egg size was determined as longer and shorter axes (diameters, $D_{1}, D_{2}$; of $N=16$ eggs each), and their volume calculated using the formula for oblate spheroids (Turner and Lawrence 1979):

$V=\left(\pi \times D_{1}^{2} \times D_{2}\right) / 6$

The embryonic stage was checked microscopically and assigned to one of six developmental categories, following the definitions by Wägele (1987):

I. Large yolk mass with no differentiation or trace of embryonic tissue (Wägele 1987, stage A1)

II. Embryonic tissue visible. Germ band present and starting to differentiate; chorion well developed; first appearance of dorsal organ (Wägele 1987, stage B2)

III. Coxal and epimeral plates present; appendages separated; first appearance of small, pigmented eyes (Wägele 1987, stage B3/4)

IV. Chorion shed, replaced by beginning of vitelline membrane; 2nd antennae firmly enrolled, covering mouthparts; eyes more strongly pigmented; small digestive glands behind eyes fill develop (Wägele 1987, stage C1)

V. Yolk sac considerably smaller and round in shape; heavily pigmented eyes develop into final oblong shape; 2nd antennae visibly segmented; digestive 
glands large and filled with liquefied yolk; dorsal segmentation nearly complete; telson extended (Wägele 1987, stage C2)

V-late. Yolk sac considerably reduced, vitelline membrane partly ruptured; this is an intermediate stage

VI. Premanca stage: cirolanid-like shape; free embryos, 2nd antennae outstretched; setae present on pleopods 1-3; coxal plates bend dorsally (Wägele 1987, stage D)

Larval biomass, elemental composition

Depending on egg size and estimated DM up to 16 larvae were taken for each developmental stage for subsequent individual determinations of DM, carbon $(C)$, nitrogen $(\mathrm{N})$, and hydrogen content $(\mathrm{H})$ following a modified protocol of Anger and Dawirs (1982). Briefly, individual larvae were rinsed in ion free water, shortly blotted on filter paper and subsequently transferred to pre-weighed tin cartridges, and oven-dried for $48 \mathrm{~h}$ at $60^{\circ} \mathrm{C}$. Samples were weighed to the nearest $0.1 \mu \mathrm{g}$ on a Sartorius M2P microbalance, to determine DM. CHN analyses were carried out with a Hekatech Model 1108 Elemental Analyzer using acetanilide as a standard. DM is given in absolute terms ( $\mu \mathrm{g}$ per egg), $\mathrm{C}, \mathrm{H}$, and $\mathrm{N}$ data are given as mass-specific values (in percent of DM).

\section{Statistical methods}

Our statistical analyses followed standard techniques (Sokal and Rohlf 1995), using a JMP (version 5.1, SAS Institute) package. Data are presented as mean values $\pm \mathrm{SD}$. The data were checked for normal distribution (Kolmogorov-Smirnov test) and homogeneity of variances (Levene's median test). Since no significant deviations were found, a Student's $t$ test was used for comparisons of mean values. Mass values $(\mathrm{C}, \mathrm{H}, \mathrm{N})$ and $\mathrm{C}: \mathrm{N}$ ratios were arcsine transformed before statistical analysis.

\section{Results}

Female fecundity, egg size, and embryo development

Ten ovigerous females were sampled from a single AGT howl taken at the Antarctic Peninsula. The total number of ovigerous females was below $10 \%$ of all caught specimens of Ceratoserolis trilobitoides. In total, 1,001 eggs of all six ontogenetic stages were extracted from the brood pouches. No significant correlation between egg number and stage with female DM or TL was found (Table 1). Number of eggs per female was independent from the ontogenetic stage.

The volume of 16 eggs per female was measured. Mean volume remained rather constant from stage I to III and increased significantly thereafter until it reached a maximum of $50.2 \mathrm{~mm}^{3}$ in stage VI (Fig. 1; Table 1). Egg volume increased by about 160 and $400 \%$ from stage I to IV and stage IV to VI, respectively (Table 1).

Changes in dry mass, elemental composition $(\mathrm{C}, \mathrm{H}, \mathrm{N})$, and $\mathrm{C}: \mathrm{N}$ ratio

The extent of developmental changes varied among the various measures: mean egg DM successively decreased from stage I $(4,803 \pm 319 \mu \mathrm{g})$ to stage IV $(4,508 \pm$ $673 \mu \mathrm{g})$, significantly dropped to a minimum of $3,644 \pm 378 \mu \mathrm{g}$ in stage $\mathrm{V}$ and finally increased again reaching a maximum value of $5,285 \pm 85 \mu \mathrm{g}$ in stage VI (Table 2; Fig. 2). Freshly hatched eggs contained on average 2,655 $\mathrm{gg} \mathrm{C}, 505 \mu \mathrm{g} \mathrm{N}$, and $398 \mu \mathrm{g} \mathrm{H}$ (Table 2). The elemental composition remained rather constant during the first four stages, showing significant differences afterwards, while the general pattern, however, is similar (Table 2). C:N mass ratio showed no significant differences from stage I (6.11) to stage $\mathrm{V}(6.17)$ and decreased significantly thereafter, due to an increase of the nitrogen content, while the carbon content remains rather stable (Fig. 3; Table 2).
Table 1 Ceratoserolis trilobitoides

Total number of eggs per female; eggs from up to two females were dissected for each stage. Of each female 16 eggs were used to calculate the mean volume; arithmetic mean \pm standard deviation (SD); values not connected by the same letter are significantly different

$T L$ total length, $D M$ dry mass, $W M$ wet mass, $w / o$ without

\begin{tabular}{|c|c|c|c|c|c|c|}
\hline \multirow[t]{3}{*}{ Embryo stage } & \multicolumn{4}{|c|}{ Female } & \multicolumn{2}{|l|}{ Egg } \\
\hline & \multirow[t]{2}{*}{$N$} & \multirow[t]{2}{*}{$\mathrm{TL}(\mathrm{mm})$} & \multicolumn{2}{|l|}{ w/o egg } & \multirow{2}{*}{$\begin{array}{l}\text { No. per female } \\
\text { Mean }\end{array}$} & \multirow{2}{*}{$\begin{array}{l}\text { Volume } \\
\text { Mean }\left(\mathrm{mm}^{3}\right) \pm \mathrm{SD}\end{array}$} \\
\hline & & & $\mathrm{WM}(\mathrm{g})$ & $\mathrm{DM}(\mathrm{g})$ & & \\
\hline I & 2 & 55.81 & 6.15 & 1.76 & 106 & $8.3 \pm 1.0 \mathrm{a}$ \\
\hline II & 1 & 56.01 & 6.92 & 1.77 & 96 & $8.5 \pm 1.0 \mathrm{a}$ \\
\hline III & 1 & 58.16 & 6.89 & 1.63 & 84 & $9.5 \pm 1.1 \mathrm{a}$ \\
\hline IV & 2 & 59.30 & 8.26 & 1.90 & 100 & $13.1 \pm 1.6 \mathrm{~b}$ \\
\hline V & 2 & 59.54 & 8.25 & 1.82 & 101 & $16.6 \pm 1.8 \mathrm{c}$ \\
\hline V-late & 1 & 58.61 & 7.88 & 1.72 & 97 & $21.9 \pm 4.4 \mathrm{~d}$ \\
\hline VI & 1 & 58.77 & 6.48 & 1.58 & 92 & $50.2 \pm 12.1 \mathrm{e}$ \\
\hline
\end{tabular}




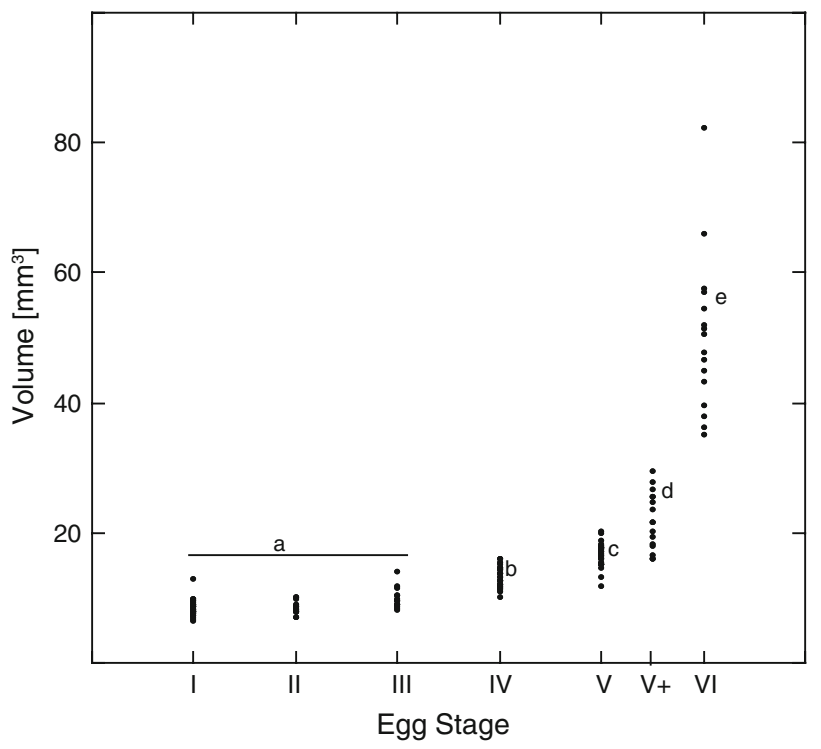

Fig. 1 Ceratoserolis trilobitoides. Mean volume $\left(\mathrm{mm}^{3}\right)$ of the six observed egg stages. Of each female 16 eggs were randomly selected. Values not connected by the same letter are significantly different

\section{Discussion}

The relative absence of pelagic larvae or drifting stages of any kind in the reproductive cycle of many marine benthic invertebrates is one of the enigmas in the ecology and evolution of Antarctic seafloor invertebrates (Thorson 1936; Pearse et al. 1991; Arntz et al. 1994; Thatje et al. 2005). This pattern was often related to environmental and physiological constraints in the cold, especially low polar temperatures and a pronounced seasonality in short periods of food availability (primary production). Latitudinal tendencies of cold adaptation have been observed in molluscs (Thorson 1936; Pörtner et al. 2005; Heilmayer et al. 2005; Peck et al. 2006), echinoderms (Shilling and Bosch 1994; Marsh et al. 1999) and especially decapod crustaceans that seemingly follow life history adaptations with decreasing temperatures along latitude, such as larger eggs reflecting higher energy investment of material origin into the single offspring that mostly comes by the cost of a reduced fecundity (Thatje et al. 2004, 2005; Fischer and Thatje 2008). Whether maternal investment in reproduction is partitioned amongst many small eggs or few large eggs might not be of immediate energetic consequence, but it is of very great ecological or evolutionary significance (Clarke and Gore 1992). In the cold waters of Antarctica, embryos and larvae of marine invertebrates have extended developmental periods and low metabolic rates, as shown for echinoderm development (Marsh et al. 1999; Shilling and Bosch 1994). The evolutionary advantage of brooding might be the advanced stage at which the larva or juvenile is released, and not the energetic cost of development per se (Clarke 1979; Pearse et al. 1991; Marsh et al. 1999; Peck et al. 2006). This energetic cost of cold adaptation (Peck 2002; Clarke 2003), however, has almost remained unstudied in the reproduction of peracarid crustaceans that in terms of diversity constitute one of the most successful groups of crustaceans in the sea.

The Antarctic serolid C. trilobitoides belongs to the few better-studied peracarid crustaceans. This species shows several features that indicate a strong energetic bottleneck as a consequence of cold adaptation: $C$. trilobitoides does only reproduce once in a lifetime (Luxmoore 1982; Wägele 1987). Furthermore, Wägele (1987) estimated that the total embryo developmental in this species lasts about two years in duration in the South Shetland Island area. In ovigerous females from the Antarctic Peninsula the number of stage I embryos per brood pouch varies from 90 to 110 (Wägele 1987; Clarke and Gore 1992), which corresponds to the number we found in our animals (Table 1). Wägele (1987) also observed a size related fecundity pattern in ovigerous females, which however, is not clearly supported by the low sample size in our study (Table 1). Another reproductive

Table 2 Ceratoserolis trilobitoides

\begin{tabular}{|c|c|c|c|c|c|c|c|}
\hline Embryo Stage & $N$ & $\begin{array}{l}\mathrm{DM}(\mu \mathrm{g} / \mathrm{egg}) \\
\text { Mean } \pm \mathrm{SD}\end{array}$ & $\begin{array}{l}\mathrm{C}(\mu \mathrm{g} / \mathrm{egg}) \\
\text { Mean } \pm \mathrm{SD}\end{array}$ & $\begin{array}{l}\mathrm{N}(\mu \mathrm{g} / \mathrm{egg}) \\
\text { Mean } \pm \mathrm{SD}\end{array}$ & $\begin{array}{l}\mathrm{H}(\mu \mathrm{g} / \mathrm{egg}) \\
\text { Mean } \pm \mathrm{SD}\end{array}$ & $\begin{array}{l}\mathrm{C} / \mathrm{N}(\text { molar) } \\
\text { Mean } \pm \mathrm{SD}\end{array}$ & $\operatorname{AFDM}(\mu \mathrm{g} / \mathrm{egg})^{a}$ \\
\hline I & 16 & $4,803 \pm 319 a$ & $2,665 \pm 177 \mathrm{a}$ & $505 \pm 29$ a,b & $398 \pm 23 a$ & $6.11 \pm 0.09 \mathrm{a}, \mathrm{b}$ & 4,579 \\
\hline II & 7 & $4,487 \pm 477 \mathrm{~b}$ & $2,413 \pm 212 a, b, c$ & $456 \pm 45 \mathrm{c}$ & $362 \pm 31 \mathrm{a}, \mathrm{b}$ & $6.18 \pm 0.09 \mathrm{a}$ & 4,277 \\
\hline III & 6 & $4,721 \pm 260 \mathrm{a}, \mathrm{b}$ & $2,597 \pm 131 \mathrm{a}, \mathrm{b}$ & $499 \pm 23$ a,b,c & $386 \pm 19 b, c$ & $6.06 \pm 0.07 \mathrm{~b}$ & 4,480 \\
\hline IV & 7 & $4,508 \pm 673 \mathrm{a}, \mathrm{b}$ & $2,349 \pm 322 \mathrm{a}$ & $467 \pm 80 \mathrm{c}$ & $354 \pm 47 \mathrm{c}$ & $6.13 \pm 0.09 \mathrm{a}, \mathrm{b}$ & 4,284 \\
\hline V & 6 & $3,644 \pm 378 c$ & $1,938 \pm 213 \mathrm{~d}$ & $366 \pm 36 \mathrm{~d}$ & $291 \pm 32 d$ & $6.17 \pm 0.10 \mathrm{a}, \mathrm{b}$ & 3,369 \\
\hline V-late & 8 & $4,574 \pm 363 a, b$ & $2,338 \pm 218 c$ & $478 \pm 40 \mathrm{~b}, \mathrm{c}$ & $348 \pm 33 \mathrm{e}$ & $5.70 \pm 0.06 \mathrm{c}$ & 4,224 \\
\hline VI & 5 & $5,285 \pm 85 \mathrm{~d}$ & $2,543 \pm 55 \mathrm{a}, \mathrm{b}, \mathrm{c}$ & $542 \pm 6 \mathrm{a}$ & $389 \pm 9 \mathrm{f}$ & $5.47 \pm 0.04 \mathrm{~d}$ & 4,881 \\
\hline
\end{tabular}

Dry mass (DM), ash-free dry mass (AFDM) and mass of specific elemental composition, carbon (C), nitrogen (N), hydrogen (H), C:N ratio throughout embryonic development; all embryos have been measured individually; arithmetic mean values \pm standard deviations (SD); values not connected by the same letter are significantly different

${ }^{a}$ Only one value for each stage could be measured 


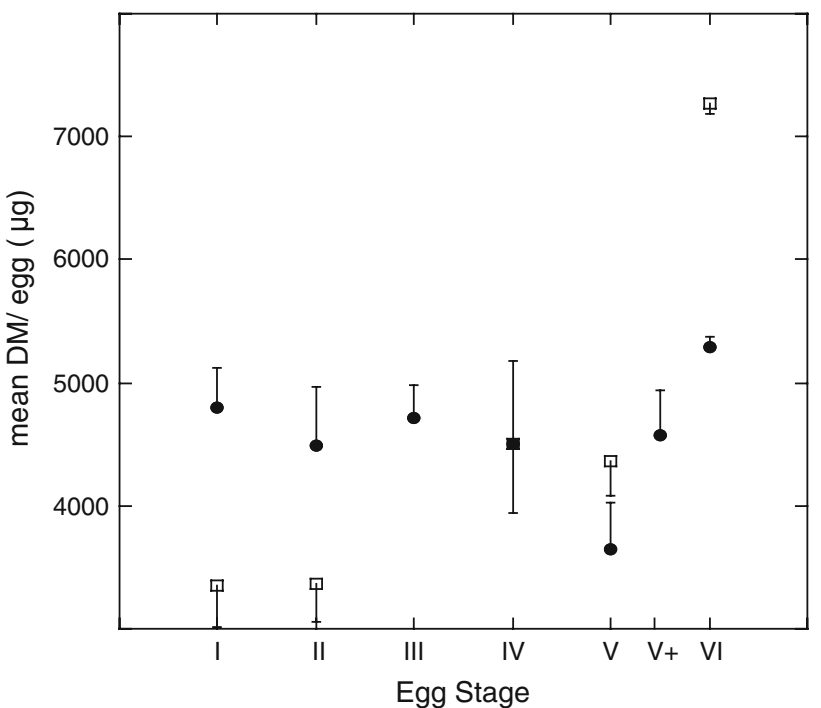

Fig. 2 Ceratoserolis trilobitoides. Comparison of mean dry mass per egg in the six stages; values from this study closed circles; values taken from Luxmoore (1982) open squares. Values given by Luxmoore (1982) are assigned to the six different eggs stages defined in this study. Please note: data are not available for all stages

adaptation indicating the existence of energetic bottleneck in this species is observed with increasing latitude: Ceratoserolis trilobitoides in the south-eastern Weddell Sea bear fewer and larger eggs compared with individuals from lower latitude South Georgia and the Antarctic Peninsula region (Gorny et al. 1992; Clarke and Gore 1992; Wägele 1987). Clarke and Gore (1992) observed a latitudinal cline in stage I embryos represented by increasing DM towards higher latitudes. They reported a mean DM of $4.65 \mathrm{mg}$ for embryos from Elephant Island, which is in the same order of magnitude than values from this study $(4.8 \pm 0.3 \mathrm{mg})$. The only mass data available for more advanced embryo stages are reported by Luxmoore (1982) for individuals sampled at Signy Island. Keeping in mind that there might be a latitudinal cline for these stages as well, the growth pattern described for C. trilobitoides from Signy Island and the Antarctic Peninsula are similar (Fig. 2), showing a significant increase of DM in the premanca stage.

Luxmoore (1982) observed a positive correlation in the number of embryos and female $C$. trilobitoides size during all ontogenetic stages, with the exception of the last the premanca stage. While he argued that the beginning of embryo release in this stage might explain the decrease in embryo number, we hypothesize that cannibalism could be responsible for the significant increase of embryo DM at this stage of development (Fig. 3).

The premanca stage (stage VI, Fig. 4) remains in the marsupium for some weeks (Wägele 1987) and the apparent absence of marsupial embryo mortality

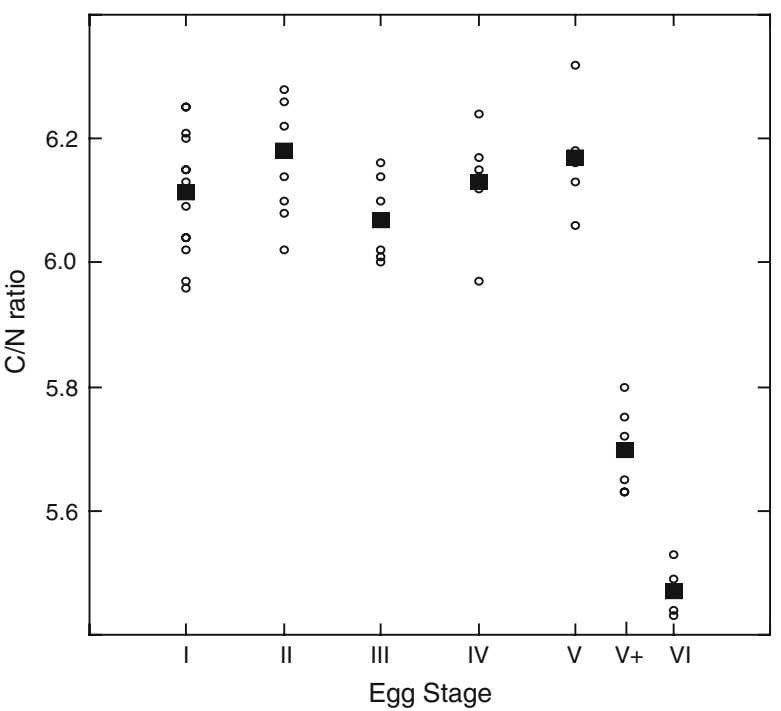

Fig. 3 C:N ratio throughout embryonic development of Ceratoserolis trilobitoides. Circles individual values; Squares mean value $(N=5-16)$

(Luxmoore 1982) is confirmed in this work. Luxmoore (1982) observed the tendency of a steep increase in DM in the premanca stage, which is supported by the present study (Table 2; Fig. 2). In the present work, the significant and remarkably drastic drop in the $\mathrm{C} / \mathrm{N}$ ratio with the late$\mathrm{V}$ and premanca stage indicates strong depletion of lipid reserves of maternal origin (Anger 2001) previously also recorded by Luxmoore (1982). Interestingly, DM increases significantly in the premanca stage in both studies. Luxmoore suggested that mineral uptake could account for this increase during late embryogenesis, which would result in an increase of ash content, and could not be observed in our data (Table 2). However, we hypothesize that a DM increase from stage V embryos to the premanca by about $170 \%$ in Luxmoore's study and about $150 \%$ in the present work cannot be explained by mineral uptake alone. The changes in the C:N ratio and the increase in DM could indeed indicate a shift from a lipid to a protein-based metabolism, the latter being indicative of active feeding (for discussion see Anger 2001). The premanca stage is morphologically fully advanced (Fig. 4; see also Wägele 1987). Furthermore, we hypothesize that, although previously observed in amphipod species (Sheader and Chia 1970), a return of juveniles into the marsupium of C. trilobitoides is unlikely due to the species' morphology and ecology. C. trilobitoides lives buried in muddy to sandy sediment, which should make a juvenile return into marsupium rather difficult. Alternatively, it might be hypothesised that with the fresh water flow through the brood pouch nutrients are provided by the female, i.e. when feeding. Another energy source might be the dissolved organic matter (e.g. amino acids and fatty acids) from 


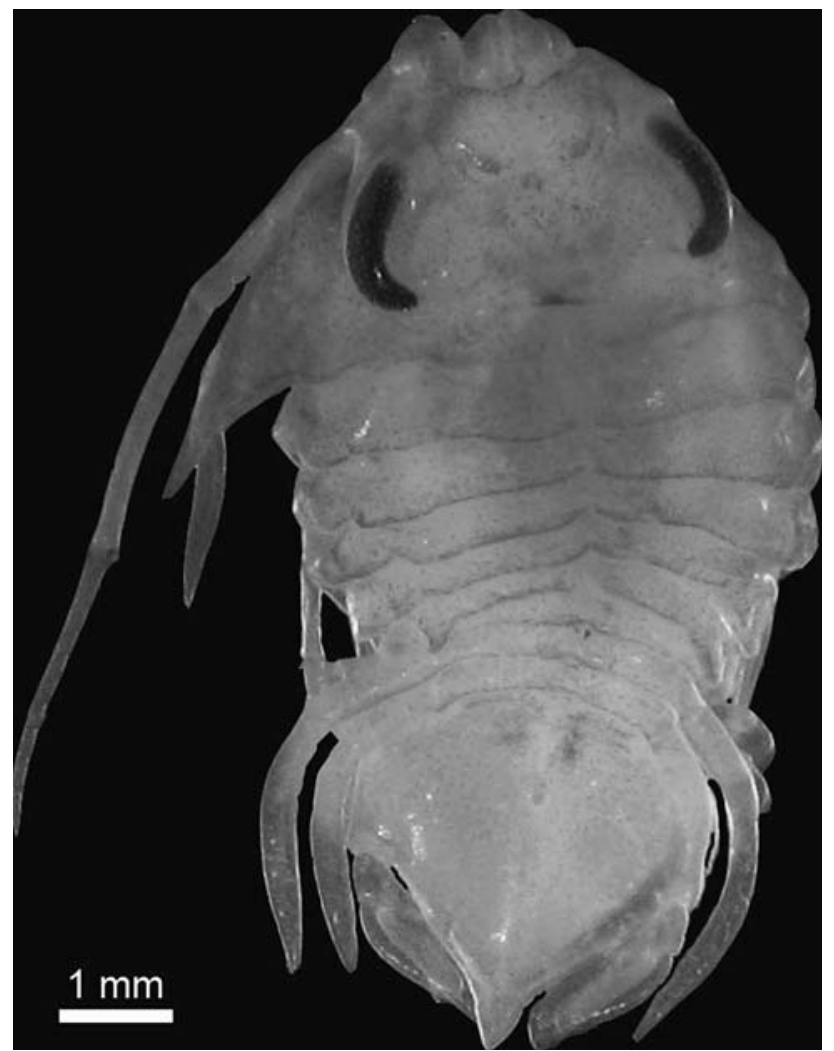

Fig. 4 Ceratoserolis trilobitoides. Dorsal view of stage VI embryo (=Premanca); scale bar $1 \mathrm{~mm}$

seawater, as already shown for the embryonic development of Antarctic echinoderms (Shilling and Bosch 1994). In C. trilobitoides, dissolved organic matter could likely be the source of increased $\mathrm{N}$ contents in the premanca stages leading to a declining $\mathrm{C} / \mathrm{N}$ ratio (Table 2). To prove this hypothesis requires an extensive experimental set-up and was not possible in the present study.

Cannibalism among early life history stages might be an evolutionary advantage of a species that exhibits low fecundity as a consequence of evolutionary temperature adaptation (Clarke 2003). Brood protection is one possibility to enhance the survival rates of few young and an advantage in the Peracarida. However, marsupial space is limited and egg volume increase by 400-600\% throughout embryogenesis (this study; Luxmoore 1982) further constrains brood size. Early selection for the fittest among the offspring could thus be interpreted as an extreme energetic and ecological adaptation to life in polar waters. The suggestion of cannibalism is also supported by the observed absence of any brood mortality in studies of C. trilobitoides. Brood mortality, however, is a common feature in other peracarids (e.g. Johnson et al. 2001; Ford et al. 2003).

The present study underlines the importance of autecological studies in Antarctic invertebrates in order to enhance our understanding of life history adaptations to environmental bottlenecks in the polar context.

Acknowledgments We would like to thank Christoph Held (AWI, Bremerhaven) for his verification of species identity of the Ceratoserolis specimens used in this study. Constanze von Waldhausen and Sönke Fischer are acknowledged for technical support with CHN measurements. Our thanks are due to the officers and crew of the RV Polarstern as well as to Julian Gutt for organizing the Polarstern Expedition ANT XXIII-8. The manuscript could be improved thanks to valuable comments of Andrew Clarke and an anonymous reviewer. The first author's work is partly supported by a "Marie Curie Fellowship" from the European Commission under the FP6 (Contract No: MEIF-CT-2006-041913).

\section{References}

Anger K, Dawirs RR (1982) Elemental composition (C, N, H) and energy in growing and starving larvae of Hyas araneus (Decapoda, Majidae). Fish Bull 80:419-433

Anger K (2001) The biology of decapod crustacean larvae. Crustacean issues, 14. AA Balkema, Lisse

Arntz WE, Brey T, Gallardo VA (1994) Antarctic zoobenthos. Oceanogr Mar Biol Ann Rev 32:241-304

Aronson RB, Thatje S, Clarke A, Peck LS, Blake DB, Wilga CD, Seibel BA (2007) Climate change and invasibility of the Antarctic benthos. Ann Rev Ecol Evol Syst 38:129-154

Brandt A (1991) Origin of Antarctic Isopoda (Crustacea, Malacostraca). Mar Biol 103:77-86

Clarke A (1979) On living in cold water: K-strategies in Antarctic benthos. Mar Biol 55:111-119

Clarke A (2003) Costs and consequences of evolutionary temperature adaptation. Trends Ecol Evol 18:573-581

Clarke A, Gore D (1992) Egg size and composition in Ceratoserolis (Crustacea: Isopoda) from the Weddell Sea. Polar Biol 12:129134

Clarke A, Skadsheim A, Holmes LJ (1985) Lipid biochemistry and reproductive biology in two species of Gammaridae (Crustacea: Amphipoda). Mar Biol 88:247-263

De Broyer C, Jazdzewski K (1993) Contribution to the marine biodiversity inventory: a checklist of the Amphipoda (Crustacea) of the Southern Ocean. Doc Trav IRSNB 73:1-154

Fischer S, Thatje S (2008) Temperature-induced oviposition in the brachyuran crab Cancer setosus along a latitudinal cline: aquaria experiments and analysis of field data. J Exp Mar Biol Ecol 357:157-164

Ford AT, Fernandes TF, Ridder SA, Read PA, Robinson CD, Davies IM (2003) Reproduction in the amphipod, Echinogammarus marinus: a comparison between normal and intersex specimens. J Mar Biol Ass UK 83:937-940

Gutt J (2006) Coexistence of macro-zoobenthic species on the Antarctic shelf: An attempt to link ecological theory and results. Deep Sea Res II 53:1009-1028

Gutt J (ed) (2008) The expedition ANTARKTIS-XXIII/8 of the research vessel "Polarstern" in 2006/2007: ANT-XXIII/8; 23 November 2006-30 January 2007 Cape Town-Punta Arenas. Berichte zur Polar- und Meeresforschung $=$ Reports on polar and marine research, 569, $153 \mathrm{pp}$

Gorny M, Arntz WE, Clarke A, Gore DJ (1992) Reproductive biology of caridean decapods from the Weddell Sea. Polar Biol 12:111120

Heilmayer O, Honnen C, Jacob U, Chiantore M, Cattaneo-Vietti R, Brey $\mathrm{T}$ (2005) Temperature effects on summer growth rates in 
the Antarctic scallop, Adamussium colbecki. Polar Biol 28:523527

Held C (2000) Phylogeny and biogeography of serolid isopods (Crustacea, Isopoda, Serolidae) and the use of ribosomal expansion segments in molecular systematics. Mol Phyl Evol $15: 165-178$

Held C (2003) Molecular evidence for cryptic speciation within the widespread Antarctic crustacean Ceratoserolis trilobitoides (Crustacea, Isopoda). In: Huiskes AHL, Gieskes WWC, Rozema J, Schorno RML, van der Vies SM, Wolff WJ (eds) Antarctic biology in a global context. Backhuys Publishers, Leiden, pp 135-139

Johnson WS, Stevens M, Watling L (2001) Reproduction and development of marine peracaridans. Adv Mar Biol 39:107-261

Leese F, Held C (2008) Identification and characterization of microsatellites from the Antarctic isopod Ceratoserolis trilobitoides: nuclear evidence for cryptic species. Conserv Genet. doi: 10.1007/s10592-007-9491-z

Lörz AN, Held C (2004) A preliminary molecular and morphological phylogeny of the Antarctic Epimeriidae and Iphimediidae (Crustacea, Amphipoda). Mol Phylogenet Evol 31:4-15

Luxmoore RA (1982) The reproductive biology of some serolid isopods from the Antarctic. Polar Biol 1:3-11

Marsh AG, Leong PKK, Manahan DT (1999) Energy metabolism during embryonic development and larval growth of an Antarctic sea urchin. J Exp Biol 202:2041-2050

Pearse JS, Lockhart SJ (2004) Reproduction in cold water: paradigm changes in the 20th century and a role for cidaroid sea urchins. Deep Sea Res II 51:1533-1549

Pearse JS, McClintock JB, Bosch I (1991) Reproduction of Antarctic benthic marine invertebrates: tempos, modes and timing. Am Zool 31:65-80

Peck LS (2002) Ecophysiology of Antarctic marine ectotherms: limits to life. Polar Biol 25:31-40

Peck LS, Convey P, Barnes DKA (2006) Environmental constraints on life histories in Antarctic ecosystems: tempos, timings and predictability. Biol Rev 81:75-109

Picken GB (1980) Reproductive adaptations of Antarctic benthic invertebrates. Biol J Linn Soc 13:67-75

Pörtner HO, Storch D, Heilmayer O (2005) Constraints and trade-offs in climate dependent adaptation: energy budgets and growth in a latitudinal cline. Sci Mar 69:39-55
Raupach MJ, Thatje S (2006) Two new records of the rare parasite Zonophryxus quinquedens Barnard, 1913 (Crustacea, Isopoda, Dajidae): ecological and phylogenetic implications. Polar Biol 29:439-443

Rehm P, Thatje S, Arntz WE, Brandt A, Heilmayer O (2006) Distribution and composition of macrozoobenthic communities along a Victoria-Land Transect (Ross Sea, Antarctica). Polar Biol 29:782-790

Sheader M, Chia F-S (1970) Development, fecundity and brooding behaviour of the amphipod Marinogammarus obtusatus. J Mar Biol Ass UK 50:1079-1099

Shilling FM, Bosch I (1994) 'Pre-feeding' embryos of Antarctic and temperate echinoderms use dissolved organic material for growth and metabolic needs. Mar Ecol Prog Ser 109:173-181

Sokal RR, Rohlf FJ (1995) Biometry: the principles and practice of statistics in biological research. Freeman, New York

Stanwell-Smith D, Peck LS, Clarke A, Murray AWA, Todd CD (1999) The distribution, abundance and seasonality of pelagic marine invertebrate larvae in the maritime Antarctic. Phil Trans R Soc Lond B 354:471-484

Thatje S, Lovrich G, Torres G, Hagen W, Anger K (2004) Changes in biomass, lipid, fatty acid and elemental composition during the abbreviated larval development of the subantarctic shrimp Campylonotus vagans. J Exp Mar Biol Ecol 301:159-174

Thatje S, Hillenbrand CD, Larter R (2005) On the origin of Antarctic marine benthic community structure. Trends Ecol Evol 20(10):534-540

Thorson G (1936) The larval development, growth and metabolism of Arctic marine bottom invertebrates compared with those of other seas. Meddr Groenl 100:1-155

Thorson G (1950) Reproductive and larval ecology of marine bottom invertebrates. Biol Rev 25:1-45

Turner R, Lawrence JM (1979) Volume and composition of echinoderm eggs: implications for the use of egg size in lifehistory models. In: Stancyk SE (ed) Reproductive ecology of marine invertebrates. University of South Carolina Press, Columbia, pp 25-40

Wägele JW (1987) On the reproductive biology of Ceratoserolis trilobitoides (Crustacea: Isopoda) latitudinal variation of fecundity and embryonic development. Polar Biol 7:11-24

White MG (1984) Marine benthos. In: Laws RM (ed) Antarctic ecology, vol 2. Academic Press, London, pp 421-461 